\title{
Tooth Structure and Fracture Strength of Cavities
}

\author{
José MONDELLI ${ }^{1}$ \\ Fábio SENE ${ }^{1}$ \\ Renata Pereira RAMOS ${ }^{2}$ \\ Ana Raquel BENETTI ${ }^{1}$ \\ ${ }^{1}$ Department of Operative Dentistry, Endodontics, and Dental Materials, \\ School of Dentistry of Bauru, University of São Paulo, Bauru, SP, Brazil \\ ${ }^{2}$ Department of Restorative Dentistry, School of Dentistry of Ribeirão Preto, \\ University of São Paulo, Ribeirão Preto, SP, Brazil
}

\begin{abstract}
This study evaluated, in vitro, the loss of tooth substance after cavity preparation for direct and indirect restorations and its relationship with fracture strength of the prepared teeth. Sixty sound human maxillary first premolars were assigned to 6 groups ( $\mathrm{n}=10$ ). MOD direct composite cavities (Groups I, II and III) and indirect inlay cavities (Groups IV, V and VI) were prepared maintaining standardized dimensions: 2-mm deep pulpal floors, 1.5-mm wide gingival walls and 2-mm high axial walls. Buccolingual width of the occlusal box was established at 1/4 (Groups I and IV), 1/3 (Groups II and V) or 1/2 (Groups III and VI) of the intercuspal distance. Teeth were weighed (digital balance accurate to $0.001 \mathrm{~g}$ ) before and after preparation to record tooth substance mass lost during cavity preparation. The prepared teeth were submitted to occlusal loading to determine their fracture strength using a universal testing machine at a crosshead speed of $0.5 \mathrm{~mm} / \mathrm{min}$. Data were analyzed by two-way ANOVA and Tukey test $(\alpha=0.05)$. 1/4-inlay cavities had higher percent mean mass loss (9.71\%) than composite resin cavities with the same width (7.07\%). 1/3-inlay preparations also produced higher percent mean mass loss (13.91\%) than composite resin preparations with the same width (10.02\%). 1/2-inlay cavities had $21.34 \%$ of mass loss versus $16.19 \%$ for the $1 / 2$-composite resin cavities. Fracture strength means (in kgf) were: GI = 187.65; GII = 143.62; GIII = 74.10; GIV = 164.22; GV = 101.92; GVI = 50.35. Statistically significant difference ( $<0.05)$ were observed between Groups I and IV, II and V, III and VI. Higher tooth structure loss and lower fracture strength were recorded after preparation of inlay cavities, regardless of the width of the occlusal box, compared to the direct composite resin cavities.
\end{abstract}

Key Words: cavity preparation, fracture strength, composite resin, inlays.

\section{INTRODUCTION}

Operative dentistry has traditionally combined the removal of carious tissue with concomitant cavity preparation while compensating eventual deficient properties of restorative materials. Consequently, reduction of sound tooth tissue for restorative purposes is not uncommon in clinical practice.

In the mid 60's and early 70's, new concepts for cavity preparation, instruments, materials and restorative techniques were introduced, widening the scopes and establishing the keystones of modern operative dentistry. The development of acid-etching and enamel bonding techniques redefined Black's principles, allowing the preparation of less invasive cavities. A new approach called "conservative extension" has been considered an important factor in the preservation of dental tissue.

Loss of dental tissue due to either caries lesion or cavity preparation reduces the fracture strength of the remaining dental structure (1-5). In several clinical situations, extensive caries lesions require less conservative cavities, which results in further dental tissue loss. Severely compromised teeth restored without regarding protective principles are at greater risk of fracturing, with unpredictable consequences $(2,5)$. This is of particular importance for posterior teeth, such as maxillary premolars, because their anatomy favors cusp deflection and fracturing under masticatory stresses $(2,6)$. 
It is well demonstrated that cavities with wider buccolingual dimensions, either restored or not, have lower fracture strength than sound teeth (4). The depth of the cavity also influences the fracture strength of teeth (7) as it relates with cusp flexibility and deflection. Moreover, increased stress is expected in the bucco and linguopulpal angles of deeper cavities. Several studies have shown that the removal of sound tooth structure during cavity preparation decreases tooth strength as cavity width and depth increases (2, 6-10).

It is also worthy mentioning that current esthetic restorative materials are hardly distinguishable from the tooth, which may lead to excessive removal of sound dental tissue and oversized cavities during replacement of old or failed fillings $(1,11)$. This problem is minimized during the removal of amalgam restorations because it is easier to distinguish metallic materials from the tooth. However, replacement of a restoration usually increases cavity dimensions $(1,3)$. Smoothening of cavity walls and rounding of internal angles are also expected to promote additional reduction of sound tissue (12).

It is not uncommon, while replacing an unsatisfactory or failed restoration, to modify the therapeutic approach. Sometimes, direct fillings give place to indirect restorative systems, which demand greater removal tooth structure to make the internal walls as expulsive as necessary to allow correct fit of the indirect restoration. Unlike direct techniques, inlays and onlays generally require more reduction of sound tooth tissue to create an adequate path of insertion (13). Dietschi (14) stated that the substitution of a direct by an indirect restoration yields greater tooth reduction because a ceramic inlay/onlay requires $10^{\circ}$ taper and $15^{\circ}$ taper are indicated for indirect composites. However, there is actually no research-based evidence determining which type or preparation, either direct (self-retained) or indirect (expulsive), demands greater removal of dental tissue. Neither has the relation between these types of cavity and fracture strength of the remaining tooth structure being determined.

Thus, the purpose of this study was to evaluate in vitro the loss of tooth structure after cavity preparation for direct or indirect restorations and its influence on the load to fracture of the the remainig structure.

\section{MATERIAL AND METHODS}

Sixty sound maxillary first premolars of similar dimensions ( $\cong 6 \mathrm{~mm}$ buccolingually; $\cong 5 \mathrm{~mm}$ mesiodistally) were stored in saline containing $0.1 \%$ thymol crystals. The teeth were previously examined at $4 \mathrm{x}$ magnification to discard those with cracks and structural defects. Six groups $(n=10)$ were formed, as follows: Groups I, II and III received direct composite preparations and Groups IV, V and VI received indirect inlay preparations.

Direct mesiooclusodistal (MOD) and indirect inlay cavities were prepared with air/water-cooled highspeed \#245 carbide and \#2136 diamond burs (KG Sorensen, Barueri, SP, Brazil), respectively. Standard cavity dimensions were established for direct and indirect preparations as being 2-mm deep pulpal walls, 2$\mathrm{mm}$ high axial walls and 1.5-mm wide gingival walls with round internal angles (Fig. 1). These dimensions were defined due to the minimum thickness required for an indirect ceramic or composite inlay restoration. Buccolingual widths were standardized at the level of the axiopulpal angle, defined as $1 / 4$ (Groups I and IV), 1/3 (Groups II and V) and 1/2 (Groups III and VI) of the intercuspal distance. The axiopulpal angle was equidistant from the gingival wall and the cavosurface angle (Fig. 1). All measurements were recorded with a digital caliper (Mettler Toledo Inc., Columbus, OH, USA).

All teeth were weighed before and after preparation using an analytical balance accurate to $0.001 \mathrm{~g}$ (Mettler-Toledo International Inc., Greifensee, Switzerland). The difference between initial and final mass determined the amount of removed dental tissue.

Fracture strength specimens were prepared by

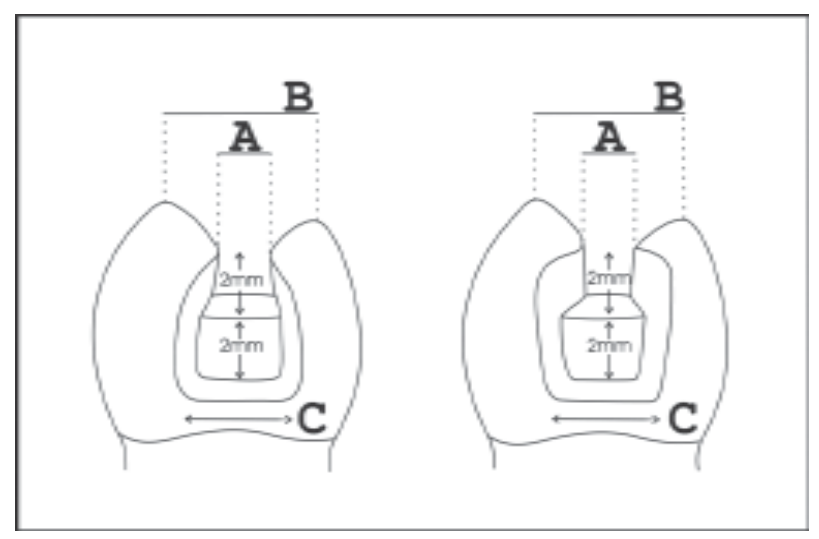

Figure 1. Contour and dimensions of direct (left) and indirect (right) cavities: A: 1/4, 1/3, 1/2 of B; C: extension of the gingival wall. 
placing the teeth in PVC rings and embedding the roots in orthophytalic resin (Redefibra Ltda., São Paulo, SP, Brazil). The crowns were exposed about $1 \mathrm{~mm}$ beyond the cementoenamel junction and niches were prepared on cusp slopes to facilitate adaptation of the tip of the testing machine. This prevented slipping of the steel cylinder and directed force application axially. The cylinder used for occlusal loading test was connected to the universal testing machine. Specimens were positioned in a clamping device, in such a way that the cylinder contacted both cusps simultaneously. Load to fracture was applied using a universal testing machine (Kratos K2000MP, M970201, Kratos Industrial Machinery Division, Wharfside, Manchester, UK) with load cell of $2000 \mathrm{~kg}$ at a crosshead speed of $0.5 \mathrm{~mm} / \mathrm{min}$.

Data were analyzed statistically by two-way analysis of variance and Tukey's multiple-comparison test at 5\% significance level.

\section{RESULTS}

Teeth prepared for 1/4-inlay cavities presented higher percent mean mass loss $(9.71 \%)$ than $1 / 4$ composite resin cavities (7.07\%). Likewise, percent mean mass loss for 1/3-inlay cavities (13.91\%) was higher than that of composite resin cavities with the same width (10.02\%). The 1/2-inlay cavities and 1/2composite resin cavities presented $21.34 \%$ and $16.19 \%$ tooth reduction, respectively. Regarding mass loss (Table 1), two-way ANOVA detected significant differences among the groups regarding buccolingual cavity width $(\mathrm{F}=186.16 ; \mathrm{p}=0.001)$, type of cavity $(\mathrm{F}=88.68 ; \mathrm{p}=0.001)$ and interaction effect $(\mathrm{F}=4.80$;

Table 1. Mass loss for the experimental groups (percent weight loss \pm standard deviation).

\begin{tabular}{lccc}
\hline Group & Width & Type of cavity & \%weight loss $( \pm \mathrm{SD})$ \\
\hline I & $1 / 4$ & Composite resin & $7.07 \pm 0.096$ \\
II & $1 / 3$ & Composite resin & $10.02 \pm 1.608$ \\
III & $1 / 2$ & Composite resin & $16.19 \pm 2.438$ \\
IV & $1 / 4$ & Inlay & $9.71 \pm 1.349$ \\
V & $1 / 3$ & Inlay & $13.91 \pm 1.725$ \\
VI & $1 / 2$ & Inlay & $21.34 \pm 2.156$ \\
\hline
\end{tabular}

$\mathrm{p}=0.012$ ). Tukey's test showed statistically significant difference for loss of tooth substance among Groups I and IV, II and V, III and VI.

Fracture strength means are displayed on Table 2. Indirect $1 / 4$-inlay cavities presented $12.5 \%$ lower fracture strength than cavities for direct restorations with the same width. 1/3-inlay cavities resulted in a decrease of $29.0 \%$ in fracture strength compared with 1/3-composite resin cavities. Finally, 1/2-inlay cavities presented $32.1 \%$ lower fracture strength than $1 / 2$ composite resin cavities.

Two-way ANOVA detected statistically significant differences among groups for cavity width ( $\mathrm{F}=795.39 ; \mathrm{p}=0.001)$, type of cavity $(\mathrm{F}=161.73$; $\mathrm{p}=0.001)$ and interaction effect $(\mathrm{F}=6.72 ; \mathrm{p}=0.002)$. Tukey's test identified statistically significant differences regarding fracture strength between Groups I and IV, II and V, III and VI.

For direct preparations, $52 \%$ of the fractures occurred in the buccal cusp, $20 \%$ in the lingual cusp and $28 \%$ were longitudinal. For inlay preparations, $70 \%$ of the fractures occurred in the buccal cusp, $14 \%$ in the lingual cusp and $16 \%$ were longitudinal.

\section{DISCUSSION}

Few studies have addressed the loss of tooth structure during cavity preparation or replacement of unsatisfactory restorations. Despite the premise that indirect cavity preparations remove more tooth structure than direct preparations, no evidence has yet been found. This study has proved this premise to be true. Higher percent mass loss of teeth prepared to receive

Table 2. Fracture strength means (kgf) ( \pm standard deviation) for the experimental groups.

\begin{tabular}{lccc}
\hline Group & Width & Type of cavity & Fracture strength $( \pm$ SD $)$ \\
\hline I & $1 / 4$ & Composite resin & $187.65 \pm 10.782$ \\
II & $1 / 3$ & Composite resin & $143.62 \pm 6.685$ \\
III & $1 / 2$ & Composite resin & $74.10 \pm 7.040$ \\
IV & $1 / 4$ & Inlay & $164.22 \pm 7.856$ \\
V & $1 / 3$ & Inlay & $101.92 \pm 9.311$ \\
VI & $1 / 2$ & Inlay & $50.35 \pm 9.933$ \\
\hline
\end{tabular}


indirect restorations was recorded compared to direct cavity preparations. It is believed that the $10^{\circ}$ divergence required for indirect preparations produces further reduction of tooth structure compared to the slight convergence determined by the tapered carbide burs used for direct preparations (Fig. 2).

Additional removal of tooth structure is expected in proximal cavities, while eliminating undercuts to allow the correct path of insertion of the indirect restoration $(15,16)$. If one considers the replacement of either an amalgam or a composite resin restoration by an adhesive inlay, the removal of the carious tissue and finishing of the cavity walls will simultaneously determine a change in cavity design. Removal of undercuts and rounding of internal angles for indirect preparations may result in additional loss of sound dental tissue. Moscovich et al. (12) estimated that, in order to change an amalgam cavity into an indirect inlay cavity, $4.6 \%$ more tooth structure might be removed. However, 1.7 to 3 times additional tooth substance has been removed. Hunter et al. (1) also verified that the replacement of class II composite resin restorations increased cavity dimensions of $50 \%$ by volume.

Technical problems in cavity preparation and removal of carious tissue and undercuts may contribute to increase cavity size. In these cases, the use of composite resin or glass ionomer cement would be good

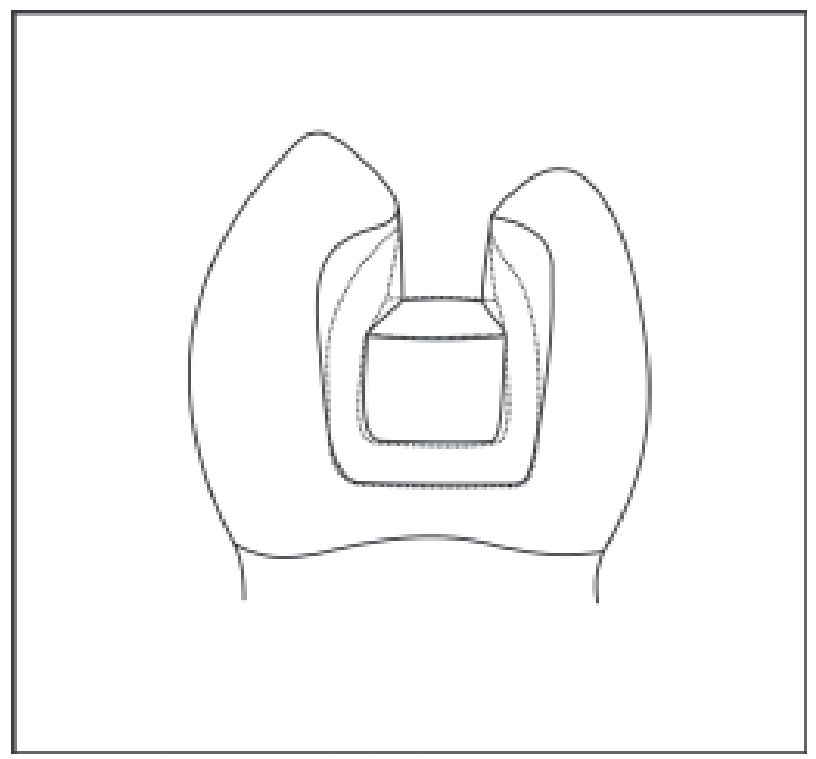

Figure 2. Overlapping of direct (dotted line) and indirect (continuous line) cavities illustrates the loss of tooth structure. alternatives to eliminate retentions without removing sound dental structure.

In clinical situations, divergent walls are expected to promote additional removal of tooth tissues because it is contrary to the propagation of the carious lesion in occlusal fissures. The removal of proximal lesions is also perpendicular to caries propagation.

In the present study, lower fracture strength was observed for all indirect cavity preparations. Mondelli et al. (4) compared the load to fracture of sound human maxillary premolars with different cavity widths, proving that the removal of tooth tissue significantly affects the load to fracture of teeth. Later studies $(3,17-19)$ have also demonstrated this. Although the methodological differences may impair reliable comparisons, the findings of the present study are consistent with previous studies with similar designs and confirm the premise that the greater the buccolingual cavity width, the lower the tooth fracture strength $(2,4,5)$.

The results of a previous work (7) somewhat contradicts those of the present study and others published elsewhere $(2,4)$ because, according to them, the cavity width cannot be as important as the cavity depth as far as fracture strength is concern.

Regarding the type of fracture observed in all groups, buccal cusp fracture was more frequent than lingual fractures, although previous clinical studies have observed similar incidence of buccal and lingual cusp fracture in posterior teeth. The results of this study agree with those of Cavel et al. (20), who verified that $67 \%$ of the fractures in maxillary premolars occurred in the non-functional cusps.

In conclusion, inlay cavity preparations resulted in higher removal of tooth substance compared to direct composite cavities, probably due to the proximal flare required to remove the undercuts during indirect preparations. Fracture strength was inversely proportional to the amount of tooth structure removed, direct composite preparations having higher resistance to occlusal load fracture than indirect preparations.

\section{RESUMO}

O objetivo deste estudo foi avaliar, in vitro, a perda de estrutura dentária após o preparo cavitário para restaurações diretas e indiretas e sua relação com a resistência à fratura do dente. 60 prémolares superiores humanos foram divididos em 6 grupos $(\mathrm{n}=10)$. Cavidades MOD para resina composta direta (Grupos I, II e III) e cavidades "inlay" (Grupos IV, V e VI) foram preparadas 
mantendo dimensões padronizadas. A extensão vestíbulo-lingual da caixa oclusal foi estabelecida em 1/4 (Grupos I e IV), 1/3 (Grupos II e V) ou 1/2 (Grupos III e VI) da distância intercuspídea. Os dentes foram pesados, em uma balança de precisão, antes e após o preparo cavitário para aferir a perda de massa dentária. Os dentes preparados foram submetidos à força de compressão para determinar a resistência à fratura em uma máquina universal de ensaios sob uma velocidade de $0.5 \mathrm{~mm} / \mathrm{min}$. Os dados foram submetidos à análise de variância a dois critérios e ao teste de Tukey $(\alpha=0.05)$. As cavidades do tipo “1/4-inlay” apresentaram maior percentual de perda de massa $(9.71 \%)$ em relação às cavidades para resina composta com mesma extensão (7.07\%). As cavidades do tipo “1/3-inlay” também apresentaram maior percentual de perda de massa (13.91\%) quando comparada às cavidades para resina composta com a mesma extensão (10.02\%). As cavidades do tipo "1/2-inlay” apresentaram $21.34 \%$ de perda de massa, enquanto as cavidades com extensão de $1 / 2$ para resina composta apresentaram uma perda de $16.19 \%$. As médias de resistência à fratura (em kgf) foram: $\mathrm{GI}=187.65$; GII = 143.62; $\mathrm{GIII}=74.10 ; \mathrm{GIV}=164.22 ; \mathrm{GV}=101.92 ; \mathrm{GVI}=50.35$. Diferenças estatisticamente significantes $(p<0.5)$ foram observadas entre os Grupos I e IV, II e V, III e VI. Maior perda de estrutura dentária e menor resistência à fratura foram verificadas após os preparos do tipo “inlay” quando comparados aos preparos para resina composta direta.

\section{REFERENCES}

1. Hunter AR, Treasure ET, Hunter AJ. Increases in cavity volume associated with the removal of class 2 amalgam and composite restorations. Oper Dent 1995;20:2-6.

2. Larson TD, Douglas WH, Geistfeld RE. Effect of prepared cavities on the strength of teeth. Oper Dent 1981;6:2-5.

3. Millar BJ, Robinson PB, Davies BR. Effects of the removal of composite resin restorations on Class II cavities. British dental Journal 1992;173:210-212.

4. Mondelli J, Steagall L, Ishikiriama A, de Lima Navarro MF, Soares FB. Fracture strength of human teeth with cavity preparations. J Prosthet Dent 1980;43:419-422.

5. Mondelli RF, Barbosa WF, Mondelli J, Franco EB, Carvalho RM. Fracture strength of weakened human premolars restored with amalgam with and without cusp coverage. Amer J Dent 1998;11:181-84.
6. Jagadish S, Yogesh BG. Fracture resistance of teeth with Class 2 silver amalgam, posterior composite, and glass cermet restorations. Oper Dent 1990;15:42-47.

7. Blaser PK, Lund MR, Cochran MA, Potter RH. Effect of designs of Class 2 preparations on resistance of teeth to fracture. Oper Dent 1983;8:6-10.

8. El-Sherif MH, Halhoul MN, Kamar AA, Nour el-Din A Fracture strength of premolars with Class 2 silver amalgam restorations. Oper Dent 1988;13:50-53.

9. Gelb MN, Barouch E, Simonsen RJ. Resistance to cusp fracture in class II prepared and restored premolars. J Prosthet Dent 1986;55:184-185.

10. Stampalia LL, Nicholls JI, Brudvik JS, Jones DW. Fracture resistance of teeth with resin-bonded restorations. J Prosthet Dent 1986;55:694-698.

11. Krejci I, Lieber CM, Lutz F. Time required to remove totally bonded tooth-colored posterior restorations and related tooth substance loss. Dent Mater 1995;11:34-40.

12. Moscovich H, Creugers NH, De Kanter RJ, Roeters FJ. Loss of sound tooth structure when replacing amalgam restorations by adhesive inlays. Oper Dent 1998;23:327-331.

13. Roulet JF, Spreafico R. Esthetic posterior indirect restorations. Advances in Operative Dentistry: contemporary clinical practice. Berlin: Quintessence Publishing; 2001.

14. Dietschi D, Spreafico R. Adhesive metal-free restoration: current concepts for the esthetic treatment of posterior teeth. Berlin: Quintessence Publishing; 1997.

15. Basset RW, Ingraham R, Koser JR. An atlas of cast gold procedures. Buena Park: West Orange County Publishing Company; 1964.

16. Shillingburg HT, Jacobi R, Brackett SE. Fundamentals of tooth preparations for cast metal and porcelain restorations. Berlin: Quintessence Publishing; 1988.

17. Camacho GB, Goncalves M, Nonaka T, Osorio AB. Fracture strength of restored premolars. Amer J Dent 2007;20:121124.

18. Franca FM, Worschech CC, Paulillo LA, Martins LR, Lovadino JR. Fracture resistance of premolar teeth restored with different filling techniques. J Contemp Dent Pract 2005; 15:62-69.

19. Santos MJ, Bezerra RB. Fracture resistance of maxillary premolars restored with direct and indirect adhesive techniques. J Canadian Dent Assoc 2005;71:585.

20. Cavel WT, Kelsey WP, Blankenau RJ. An in vivo study of cuspal fracture. J Prosthet Dent 1985;53:38-42. 